\title{
Trousseau's syndrome in a patient with gastric cancer
}

\section{Mototsugu Matsunaga, Masaru Fukahori, Tomoyuki Ushijima, Keisuke Miwa}

Multidisciplinary Treatment Cancer Center, Kurume University Hospital, Kurume, Japan

\section{Correspondence to} Dr Mototsugu Matsunaga, mmandmacgyver@yahoo.co.jp

Accepted 26 November 2015
CrossMark

To cite: Matsunaga $M$, Fukahori M, Ushijima T, et al. BMJ Case Rep Published online: [please include Day Month Year] doi:10.1136/bcr-2015213284

\section{DESCRIPTION}

A 74-year-old man, who had been receiving S-1 plus cisplatin combination chemotherapy for gastric cancer and metastatic disease of the liver, ${ }^{1}$ developed disorientation, amnesia and anorexia on day 13 of the fourth cycle of the chemotherapy regime. On day 16 , he was reviewed in the outpatients department and was admitted as an emergency. MRI of the brain obtained on his admission showed no metastatic disease or haemorrhage, but revealed striking areas of low signal intensity on T1-weighted images, and abnormally high signal intensity on diffusion-weighted images, in the right occipital lobe (figure 1), consistent with cerebral infarction. MR angiography, however, showed no abnormal findings (figure 2). ECG and echocardiogram were also normal. Therefore, the patient was diagnosed with Trousseau's syndrome associated with gastric cancer ${ }^{2}$ due to hypercoagulability secondary to active malignancy, and anticoagulation therapy was initiated. $\mathrm{He}$ was in remission after the treatment started, but had a further cerebral infarction 14 days after hospital admission and died 3 days later.

Trousseau's syndrome is a well-known manifestation of thrombosis due to abnormalities of the
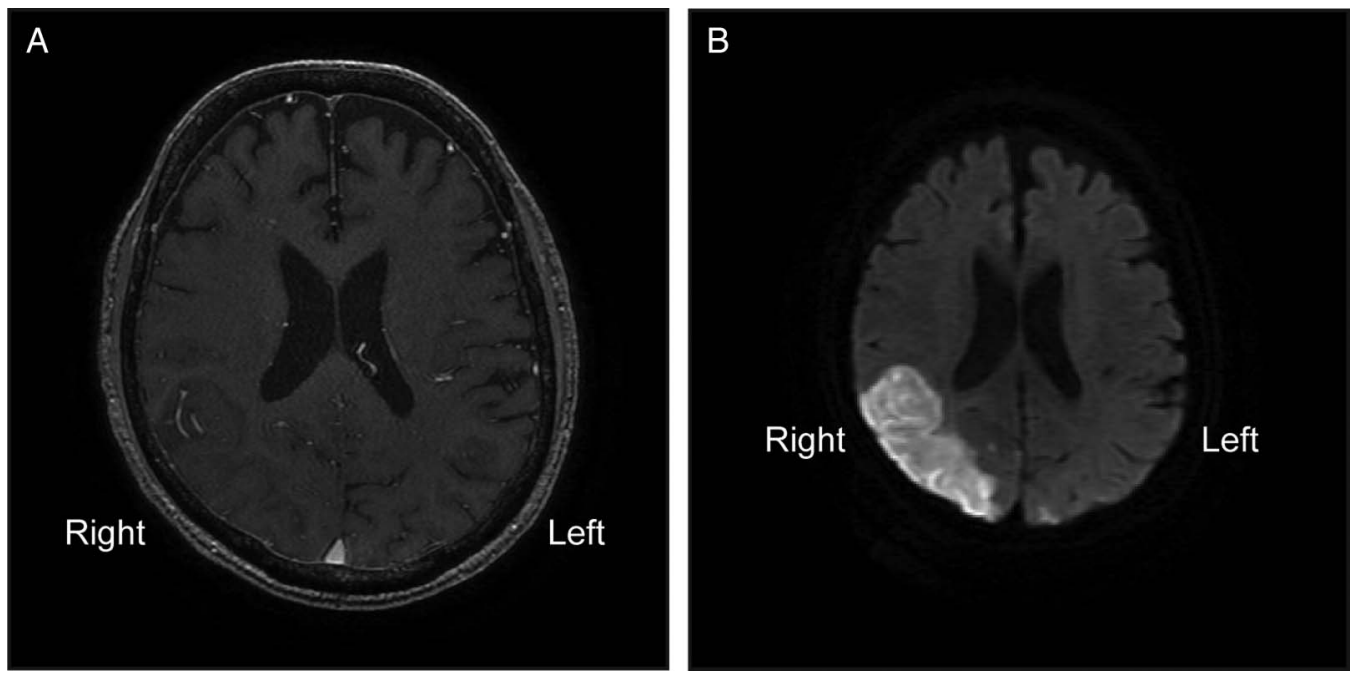

Figure 1 Areas in the right occipital lobe of the patient's brain with (A) low signal intensity on T1-weighted MRI and (B) abnormally high signal intensity on diffusion-weighted images.

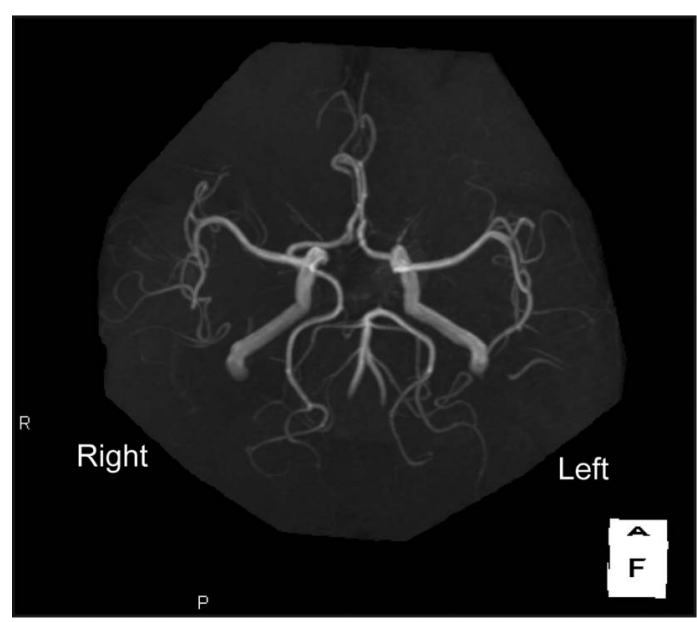

Figure 2 MR angiography showing no abnormal findings such as cerebral artery occlusion or aneurysm.

coagulation-fibrinolysis system often associated with malignancy, ${ }^{2}$ and cerebral infarction due to Trousseau's syndrome has a particularly poor prognosis. ${ }^{3}$ 


\section{Learning points}

- Coagulation testing should be performed regularly on patients with cancer, with sufficient attention being focused on the onset of cerebral infarction, because the coagulation-fibrinolysis system is often impaired in these patients as a consequence of their malignancy. In our patient, prothrombin time and activated partial thromboplastin time were normal, but fibrinogen/fibrin degradation product and cross-linked fibrin degradation product levels were elevated.

- The differential diagnosis of patients with cancer presenting with neurological symptoms needs to include Trousseau's syndrome.
Competing interests None declared.

Patient consent Obtained.

Provenance and peer review Not commissioned; externally peer reviewed.

\section{REFERENCES}

1 Koizumi W, Narahara H, Hara T, et al. S-1 plus cisplatin versus S-1 alone for first-line treatment of advanced gastric cancer (SPIRITS trial): a phase III trial. Lancet Oncol 2008:9:215-21.

2 Varki A. Trousseau's syndrome: multiple definitions and multiple mechanisms. Blood 2007:110:1723-9.

3 Cestari DM, Weine DM, Panageas KS, et al. Stroke in patients with cancer: incidence and etiology. Neurology 2004;62:2025-30.

Copyright 2015 BMJ Publishing Group. All rights reserved. For permission to reuse any of this content visit http://group.bmi.com/group/rights-licensing/permissions.

BMJ Case Report Fellows may re-use this article for personal use and teaching without any further permission.

Become a Fellow of BMJ Case Reports today and you can:

- Submit as many cases as you like

- Enjoy fast sympathetic peer review and rapid publication of accepted articles

- Access all the published articles

- Re-use any of the published material for personal use and teaching without further permission

For information on Institutional Fellowships contact consortiasales@bmjgroup.com

Visit casereports.bmj.com for more articles like this and to become a Fellow 